\title{
Taxonomy of the Genus Bacillus and Related Genera: The Aerobic Endospore-Forming Bacteria
}

\author{
Dagmar Fritze
}

DSMZ-Deutsche Sammlung von Mikroorganismen und Zellkulturen, Mascheroder Weg 1b, 38124 Braunschweig, Germany. Accepted for publication 22 June 2004.

\begin{abstract}
Fritze, D. 2004. Taxonomy of the genus Bacillus and related genera: The aerobic endospore-forming bacteria. Phytopathology 94:1245-1248.

The conspicuous morphological feature of endospore formation has lent itself from early on as an easily recognized property for taxonomic differentiation. Prior to 1980, the year of the compilation of the Approved Lists of Bacterial Names, four genera of aerobic endospore-forming bacteria had been established, with the genus Bacillus being the largest and most

prominent. However, modern developments in taxonomic methodology have helped to reveal an enormous breadth in physiological and genetical diversity within the groups of aerobic bacteria that have endospore formation as a common trait. To better reflect this existing diversity and to provide more appropriate taxonomic arrangements, numerous valid descriptions of new genera and new species have been realized as well as many reclassifications that became necessary. Today, the group of aerobic endospore-forming bacteria embraces more than 25 genera and over 200 species.
\end{abstract}

Established by Cohn in 1872 (6), the genus Bacillus has undergone considerable taxonomic changes. Starting off with two prominent and truly endospore-forming species, Bacillus anthracis and B. subtilis (until the early 1900s some taxonomists did not restrict the genus to endospore-forming bacteria), the number of species allocated to this genus increased to an incredible 146 in the 5th edition of Bergey's Manual of Determinative Bacteriology (3). Meticulous comparative studies of Smith et al. (16) and Gordon et al. (10) on 1,114 strains of aerobic endospore-forming bacteria (AEFB) helped to reduce this number to 22 well-defined species in the 8th edition of Bergey's Manual of Determinative Bacteriology (4). These researchers made a case for being "lumpers" rather than "splitters" in their taxonomic work, thus being able to present morphologically and physiologically well-defined taxa while accepting that these taxa might later again be taken apart to form better species when better methods became available. The advantage of their approach is that today modern taxonomy still can confidently rely on their results.

A general new starting point for bacterial taxonomy occurred in 1980 with the publication of the Approved Lists of Bacterial Names (14) where numerous taxonomic experts had cooperated in establishing a comprehensive and agreed upon list of accepted names of bacterial species. Herein, 38 species of AEFB were listed of which 31 were allocated to the genus Bacillus and 7 to other aerobic endospore-forming genera. An amended edition was published in 1989 (15). From this base, a steady increase was seen that lately developed into a virtual explosion of newly and validly described species of AEFB.

Present systematic status. Two factors are chiefly responsible for this rapid increase in named species. One is the application of more diverse and intelligent methods for the enrichment and isolation processes to better account for the true physiological

Corresponding author: D. Fritze; E-mail address: dfr@dsmz.de

Publication no. P-2004-0916-02O

(c) 2004 The American Phytopathological Society breadth and nutritional and cultural requirements of these ubiquitous organisms. The other is the development of new and ever more sophisticated methods for the characterization and identification of bacterial strains, in particular on the genetic level, of which especially the $16 \mathrm{~S}$ rRNA/DNA sequence analysis has exerted major influence.

In particular, sequence analysis has led and continues to lead, on the one hand, to the separation of groups of species from the core genus Bacillus to form new genera and, on the other hand, to the definition of novel genera to allocate new isolates. Today, Bacillus is only one out of a whole series of genera of AEFB comprising increasing numbers of validly published species. Descriptions of these genera and species are based to a varying extent upon morphological, biochemical, physiological, and chemotaxonomical traits and on the results of various molecular genetic techniques. However, while the basic systematic structure is today determined by the comparison of the sequences of the $16 \mathrm{~S}$ rRNA/DNA (18), it is understood, in areas where discrimination through this method is insufficient or unsatisfactory, that classical methods are still useful and newly developed methods need to be applied.

Table 1 shows the genera of AEFB and their closest neighbors according to $16 \mathrm{~S}$ rRNA/DNA sequence similarities as listed in the second edition of Taxonomic Outline of Bergey's Manual of Systematic Bacteriology (9). Within the order Bacillales, this method groups non-spore-forming families with those that form spores, and also within families, spore-forming and non-spore-forming genera occur. In Table 1, names of spore-forming genera are highlighted in bold letters. Closer examination of these data at the species level reveals that in some cases both spore-forming and non-spore-forming bacteria are found within the same genus. Whether these are indeed organisms lacking the genes for spore formation, whether they have lost them (or part of them) during evolution, or whether they are physiologically unable to succeed in spore formation remains to be clarified.

Only four of the genera of AEFB (Bacillus, Sporolactobacillus, Sporosarcina, and Thermoactinomyces) had already been in- 
cluded in the approved lists and are still valid today. Over time, new taxa of AEFB have been designed, e.g., for organisms with an unusual physiology such as acidophiles (Alicyclobacillus and Sulfobacillus) or thermophiles (Geobacillus, Thermaerobacter, and Thermobacillus). For most of the others, phenotypic differentiation from Bacillus sensu stricto is not so clear-cut and only possible through a combination of a number of traits. For some of the genera, the determination of such traits has yet to be

TABLE 1. Systematic position of the gram-positive aerobic endosporeforming bacteria (AEFB) according to $16 \mathrm{~S}$ rRNA/DNA sequences and number of species within genera of AEFB ${ }^{\mathrm{a}}$

\begin{tabular}{|c|c|}
\hline Systematic position & No. of species/subsp. \\
\hline \multicolumn{2}{|l|}{ Domain Bacteria } \\
\hline \multicolumn{2}{|l|}{ Phylum BXIII. Firmicutes phy. nov. } \\
\hline \multicolumn{2}{|l|}{ Class III. Bacilli } \\
\hline \multicolumn{2}{|l|}{ Order I. Bacillales AL } \\
\hline \multicolumn{2}{|l|}{ Family I. Bacillaceae ${ }^{\mathrm{AL}}$} \\
\hline Genus I. Bacillus ${ }^{\mathrm{AL}}$ & $88 / 2$ \\
\hline Genus II. Amphibacillus VP & 3 \\
\hline Genus III. Anoxybacillus VP & 3 \\
\hline \multicolumn{2}{|l|}{ Genus IV. Exiguobacterium ${ }^{\mathrm{VP}}$} \\
\hline Genus V. Filobacillus VP & 1 \\
\hline Genus VI. Geobacillus VP & 10 \\
\hline Genus VII. Gracilibacillus VP & 2 \\
\hline Genus VIII. Halobacillus VP & 5 \\
\hline Genus IX. Jeotgalibacillus VP & 1 \\
\hline Genus X. Lentibacillus VP & 1 \\
\hline Genus XI. Marinibacillus VP & 1 \\
\hline Genus XII. Oceanobacillus VP & 1 \\
\hline Genus XIII. Paraliobacillus VP & 1 \\
\hline \multicolumn{2}{|l|}{ Genus XIV. Saccharococcus VP } \\
\hline Genus XV. Salibacillus VP & - \\
\hline Genus XVI. Ureibacillus VP & 2 \\
\hline Genus XVII. Virgibacillus VP & 7 \\
\hline \multicolumn{2}{|l|}{ Family II. Alicyclobacillaceae } \\
\hline Genus I. Alicyclobacillus VP & $8 / 2$ \\
\hline Genus II. Pasteuria $^{\mathrm{AL}}$ & 3 \\
\hline Genus III. Sulfobacillus VP & 3 \\
\hline \multicolumn{2}{|l|}{ Family III. Caryophanaceae ${ }^{\mathrm{AL}}$} \\
\hline \multicolumn{2}{|l|}{ Genus I. Caryophanon ${ }^{\mathrm{AL}}$} \\
\hline \multicolumn{2}{|l|}{ Family IV. Listeriaceae } \\
\hline \multicolumn{2}{|l|}{ Genus I. Listeria ${ }^{\mathrm{AL}}$} \\
\hline \multicolumn{2}{|l|}{ Genus II. Brochothrix ${ }^{\mathrm{AL}}$} \\
\hline \multicolumn{2}{|l|}{ Family V. Paenibacillaceae } \\
\hline Genus I. Paenibacillus VP & $45 / 2$ \\
\hline Genus II. Ammoniphilus VP & 2 \\
\hline Genus III. Aneurinibacillus VP & 3 \\
\hline Genus IV. Brevibacillus VP & 11 \\
\hline \multicolumn{2}{|l|}{ Genus V. Oxalophagus VP } \\
\hline \multicolumn{2}{|l|}{ Genus VI. Thermicanus VP } \\
\hline Genus VII. Thermobacillus VP & 1 \\
\hline \multicolumn{2}{|l|}{ Family VI. Planococcaceae ${ }^{\mathrm{AL}}$} \\
\hline \multicolumn{2}{|l|}{ Genus I. Planococcus AL } \\
\hline \multicolumn{2}{|l|}{ Genus II. Filibacter ${ }^{\mathrm{VP}}$} \\
\hline Genus III. Kurthia ${ }^{\mathrm{AL}}$ & \\
\hline Genus IV. Planomicrobium VP & \\
\hline Genus V. Sporosarcina ${ }^{\mathrm{AL}}$ & 3 \\
\hline Family VII. Sporolactobacillaceae & \\
\hline Genus I. Sporolactobacillus AL & $5 / 2$ \\
\hline Genus II. Marinococcus $\mathrm{VP}$ & \\
\hline Family VIII. Staphylococcaceae & \\
\hline Genus I. Staphylococcus AL & \\
\hline Genus II. Gemella ${ }^{\mathrm{AL}}$ & \\
\hline Genus III. Jeotgalicoccus VP & \\
\hline Genus IV. Macrococcus VP & \\
\hline Genus V. Salinicoccus VP & \\
\hline Family IX. Thermoactinomycetaceae & \\
\hline Genus I. Thermoactinomyces ${ }^{\mathrm{AL}}$ & 6 \\
\hline Family X. Turicibacteraceae & \\
\hline Genus I. Turicibacter ${ }^{\mathrm{AL}}$ & \\
\hline
\end{tabular}

a Sequences were taken from the Taxonomic Outline of Bergey's Manual (9). $\mathrm{AL}$ is the agreed symbol for names that are included in the Approved Lists. VP is the agreed symbol for names that have been validly published since then. Names in bold type indicate spore-forming genera. completed and differentiation is not satisfactory. All in all, today (2003) over 200 species of AEFB allocated to about 25 genera have been validly published. The most recent, nearly complete listing (up to 2002) of all original publications of new species of AEFB can be found in Fritze (8).

Taxonomic developments in two selected groups of the genus Bacillus. Certain taxa of AEFB have received considerable taxonomic attention because of their outstanding applied importance. This is especially true for two groups of organisms vernacularly called the B. subtilis group and the B. cereus group, which will both be presented to exemplify taxonomic developments in AEFB. Both groups contain bacteria with a strong plantmicrobe interactive ability.

B. subtilis is not only a renowned classical model organism for genetic research but also widely used in traditional and industrial fermentation processes as well as in agriculture. Production of enzymes, antibiotic or probiotic components, antagonistic substances or surfactants or, on the other hand, degradation of xenobiotics are only some of the long list of applications of this and related organisms.

Species of the $B$. subtilis group are closely related and thus not easily distinguishable. Cells of these organisms are less than $1 \mu \mathrm{m}$ wide, sporangia are not swollen, and spores are ellipsoidal. They are in general mesophilic with regard to temperature and neutrophilic with respect to $\mathrm{pH}$ for growth, while often being tolerant to higher $\mathrm{pH}$ levels. All members of the group are placed in $16 \mathrm{~S}$ rRNA/DNA group 1. Application of the classical phenotypic tests for the differentiation of Bacillus species (5) indicates that only for some of them have clearly discriminating features been determined. For example, B. pumilus is starch negative and hippurate positive, and $B$. licheniformis is propionate positive, grows in temperatures up to $55^{\circ} \mathrm{C}$, and is facultatively anaerobic. For others, phenotypic discrimination is weak, such as for B. atrophaeus, where pigment formation on tyrosine medium was described to differ from B. subtilis from which it is otherwise not distinguishable, and for $B$. amyloliquefaciens, where a faster acid production from lactose and a slower gluconate utilization was described in contrast to B. subtilis. The two subspecies of B. subtilis (B. subtilis subsp. subtilis and $B$. subtilis subsp. spizizenii), B. mojavensis, and B. vallismortis are not distinguishable phenotypically so far. The same is true for B. licheniformis and B. sonorensis.

The history of the presently accepted species of the $B$. subtilis group is presented in Figure 1. All species can be differentiated on the genetic level and it is to be expected that when genotypic analyses are applied to a wider range of strains of the classical species mentioned above, additional genospecies will be detected. $B$. clausii is, strictly speaking, not a member of the $B$. subtilis group; however, it is listed here for the sake of completeness, because a number of strains previously classified as B. subtilis and used as probioticum have recently been reclassified as $B$. clausii (13). Even more loosely attached to this group are the species $B$. firmus, B. lentus, and B. sporothermodurans, which are clearly distinguishable from the other species and are not further discussed.

A second group of species of major interest is the B. cereus group. While the members of this group are easily distinguished from other members of AEFB, they are difficult to distinguish from each other. Cells of these organisms are wider than $1 \mu \mathrm{m}$, sporangia are not swollen, and spores are ellipsoidal. They are in principle mesophilic and neutrophilic and are placed in $16 \mathrm{~S}$ rRNA/DNA group 1. Classical features to distinguish this group from all other AEFB are their inability to produce acid from mannitol and their production of lecithinase. Within the group, phenotypic differentiation is difficult. Two species (B. cereus and $B$. thuringiensis) are usually motile and three species (B. cereus, $B$. thuringiensis, and B. mycoides) are described as being hemolytic and penicillin resistant. B. anthracis is exclusively lysed by the gamma phage. Most of the so-called typical reactions (rhizoid 
growth of B. mycoides, crystal formation of B. thuringiensis, pathogenicity of $B$. anthracis) are culture dependent and/or plasmid coded. A nonrhizoid mycoides or pseudomycoides, a noncrystal-forming thuringiensis, or a nonpathogenic anthracis are virtually indistinguishable from a $B$. cereus. DNA/DNA hybridizations between the type strains of these species have shown unsatisfying similarities of about 50 to $60 \%$, and some of their 16S rRNA sequences are virtually identical. However, DNA/DNA hybridizations within the species $B$. anthracis reveal high (>90\%) similarity. An extensive genotypic diversity especially of the species $B$. cereus and $B$. thuringiensis has been proven by Jackson et al. (12). Only B. anthracis seems to form a relatively tight and separate genetic cluster and some correlating phenotypic properties are used in medical diagnostics (19). The species B. weihenstephanensis seems to consist of strains of B. mycoides and B. cereus.

The taxonomic development of this group over time reflects the problems researchers have with these organisms (Fig. 2). While Smith et al. (16) and Gordon et al. (10) reduced and maintained three of the then four species to variety rank due to lack of convincing discriminative properties, the four species were reinstalled later in the Approved Lists. The problem is that in this tight group such diverse organisms are assembled as a highly pathogenic risk group 3 species (B. anthracis), a diarrhea, emesis or mastitis causing risk group 2 species (B. cereus), harmless saprophytic soil inhabitants (e.g., B. mycoides), and widely used plant pest control organisms (B. thuringiensis), both of the latter assigned to the lowest risk group 1 . Most interesting is that certain strains of B. cereus are used with great success as growthpromoting animal feed additives (probiotical strains that have been proven to be nontoxigenic and which are therefore downgraded to risk group 1) and that others attract attention because of their antagonistic activity.

Risk groups (or hazard groups) are defined through the definitions for classification by the World Health Organization (1). They established a classification of four hazard groups for microorganisms (groups 1, 2, 3, and 4) applicable for work in a labora-

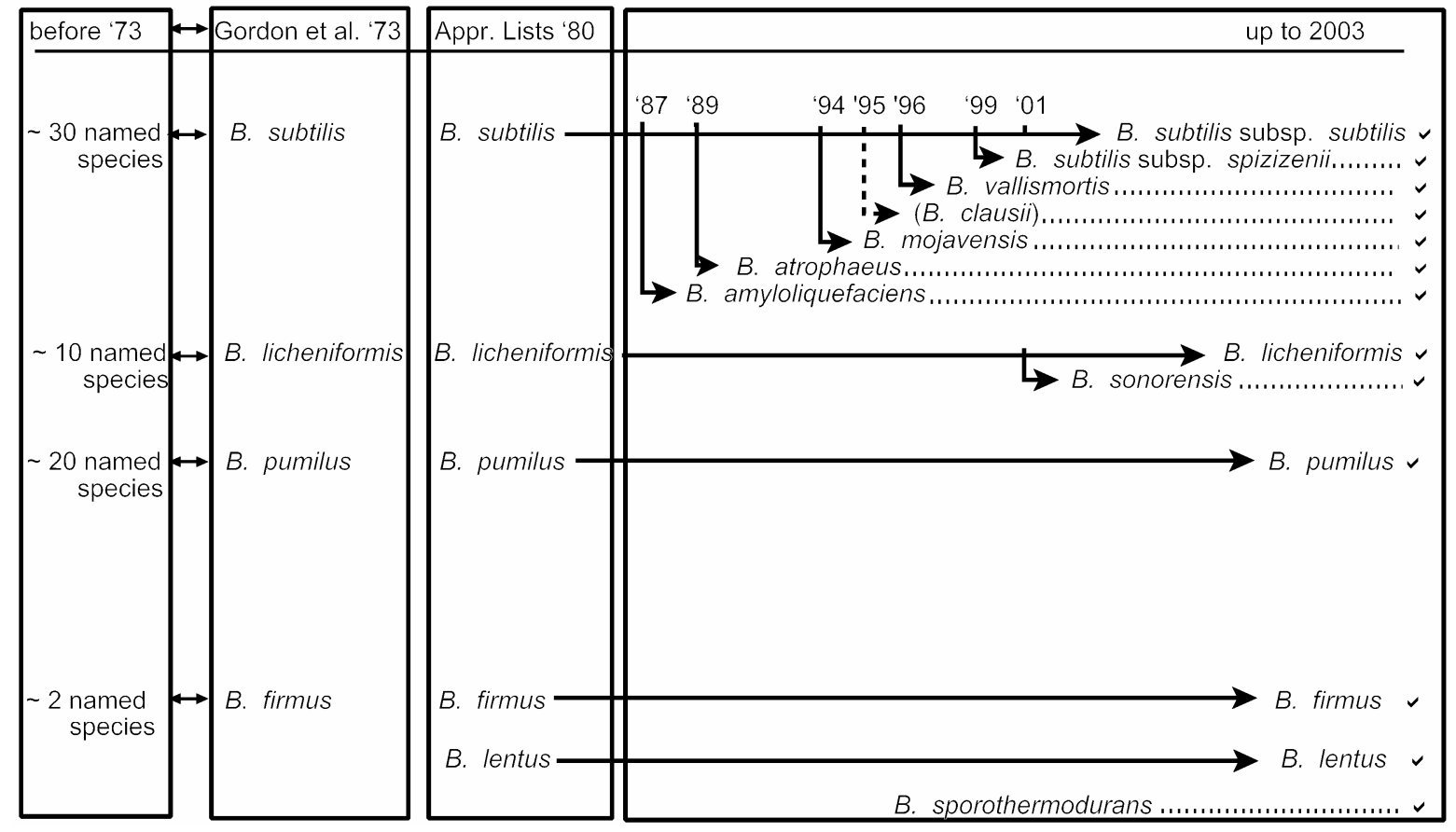

Fig. 1. Taxonomic development in the Bacillus subtilis group.

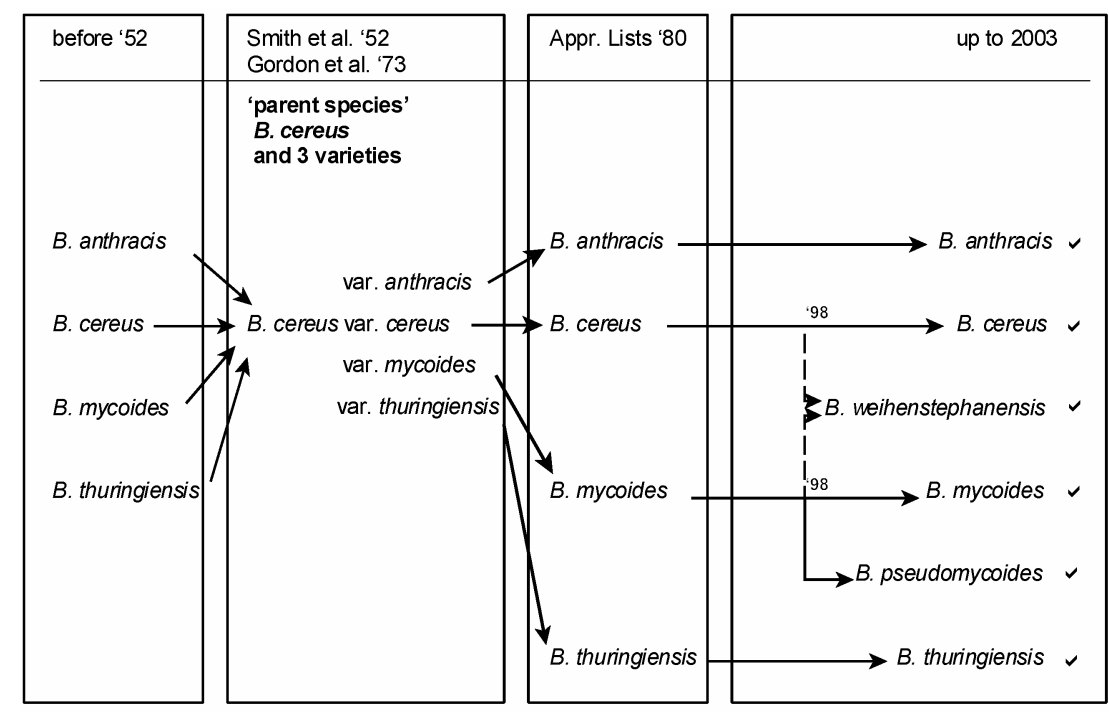

Fig. 2. Taxonomic development in the Bacillus cereus group. 
tory. Organisms are allocated to these groups according to the increasing risk they pose for human beings or animals. Allocation of species to risk groups is decided on regional or national levels. The above-mentioned allocations are according to European legislation (7) and German legislation (2), which are largely consistent with classifications of the United States, Canada, or Australia (information available from the ABSA [American Biological Safety Association] website).

Helgason et al. (11) have again discussed whether at least three of the species of this group (B. anthracis, B. cereus, and B. thuringiensis) should be regarded as one species with subspecies, while the work of Jackson et al. (12), mentioned previously, suggests the presence of even more species (or subspecies) within this group. Intensive work is going on and, indeed, needs to be done to evaluate the whole group taxonomically in more depth. The decision on redefinition of species in this group will mainly depend on the availability of appropriate methods and the agreement of taxonomists regarding how and where to set border lines between species. At least, the new definitions should be expected to serve the applied areas of sciences, such as regulatory bodies, to support their work. In addition, easy-to-check correlating diagnostic features need to be determined. According to the Ad Hoc Committee for the Re-evaluation of the Species Definition in Bacteriology (17), up to now, the final proof for conspecificity of two given bacterial strains is DNA/DNA hybridization, a laborious and time-consuming method. New and quicker methods need to be developed to substitute this method appropriately. However, it is definitely clear that within some of the above-mentioned species, which were isolated and described in the early days of bacteriology and which therefore were and still are mainly phenotypically defined, a broad range of genotypic diversity (be it species or subspecies) is hidden.

\section{LITERATURE CITED}

1. Anonymous. 1993. WHO Laboratory Biosafety Manual. 2nd ed. World Health Organization, Geneva.

2. Anonymous. 1999. Safe Biotechnology, Classification of Biological Agents, Bacteria. BG Chemie, leaflet B 006e. Jedermann-Verlag, Heidelberg.

3. Bergey, D. H., Breed, R. S., Murray, E. G. D., and Hitchens, A. P. (eds.) 1939. Bergey's Manual of Determinative Bacteriology. 5th ed. Williams and Wilkins, Baltimore.
4. Buchanan, R. E., and Gibbons, N. E. (eds.) 1974. Bergey's Manual of Determinative Bacteriology. 8th ed. Williams and Wilkins, Baltimore.

5. Claus, D., and Berkeley, R. C. W. 1986. Genus Bacillus Cohn 1872. Pages 1105-1139 in: Bergey's Manual of Systematic Bacteriology. Williams and Wilkins, Baltimore.

6. Cohn, F. 1872. Untersuchungen über Bakterien. Pages 127-224 in: Beiträge zur Biologie der Pflanzen 1, 1875 (Heft 1), J. U. Kern's Verlag (Max Müller), Breslau.

7. European Community Council Directive 2000/54/EEC of the European Parliament and of the Council of 18 September 2000 on the protection of workers from risks related to the exposure to biological agents at work (seventh individual directive within the meaning of Article 16(1) of Directive 89/391/EEC).

8. Fritze, D. 2002. Bacillus identification-traditional approaches. Pages 822 in: Applications and Systematics of Bacillus and Relatives. Blackwell Publishing, Oxford.

9. Garrity, G. M., Bell, J. A., and Lilburn, T. G. 2003. Taxonomic Outline of the Prokaryotes: Bergey's Manual of Systematic Bacteriology. doi No. http://dx.doi.org/10.1007/bergeysoutline. Published online by SpringerVerlag, New York.

10. Gordon, R. E., Haynes W. C., and Pang, C. H. 1973. The Genus Bacillus. U.S. Dep. Agric. Handb. 427.

11. Helgason, E., Økstad, O. A., Caugant, D. A., Lohanson, H. A., Fouet, A., Mock, M., Hegna, I., and Kolst $\varnothing$, A.-B. 2000. Bacillus anthracis, Bacillus cereus and Bacillus thuringiensis-One species on the basis of genetic evidence. Appl. Environ. Microbiol. 66:2627-2630.

12. Jackson, P. J., Hill, K. K., Laker, M. T., Ticknor, L. O., and Keim, P. 1999. Genetic comparison of B. anthracis and its close relatives using AFLP and PCR analysis. J. Appl. Microbiol. 87:263-269.

13. Senesi, S., Celandroni, F., Tavanti, A., and Ghelardi, E. 2001. Molecular characterization and identification of Bacillus clausii strains marketed for use in oral bacteriotherapy. Appl. Environ. Microbiol. 67:834-839.

14. Skerman, V. B. D., McGowan, V., and Sneath, P. H. A. (eds.) 1980. Approved Lists of Bacterial Names. American Society for Microbiology, Washington, DC.

15. Skerman, V. B. D., McGowan, V., and Sneath, P. H. A. (eds.) 1989. Approved Lists of Bacterial Names. Amended Edition. American Society for Microbiology, Washington, DC.

16. Smith, N. R., Gordon, R. E., and Clark, F. E. 1952. Aerobic Spore Forming Bacteria. U.S. Dep. Agric. Monogr. 16. Washington, DC.

17. Stackebrandt, E., Fredericksen, W., Garrity, G. M., Grimont, P. A. D., Kämpfer, P., Maiden, M. C. J., Nesme, X., Rossello-Mora, R., Swings, J. Trüper, H. G., Vauterin, L., Ward, A. C., and Whitman, W. B. 2002. Report of the ad hoc committee for the re-evaluation of the species definition in bacteriology. Int. J. Syst. Evol. Microbiol. 52:1034-1047.

18. Stackebrandt, E., and Swidersky, J. 2002. From phylogeny to systematics. Pages 8-22 in: Applications and Systematics of Bacillus and Relatives. Blackwell Publishing, Oxford.

19. Turnbull, P. C. B. 1999. Definitive identification of Bacillus anthracis-A review. J. Appl. Microbiol. 87:237-240. 